\title{
PENENTUAN KADAR AIR BAGI LAPIS PONDASI DAUR ULANG JALAN BERASPAL DENGAN FOAM BINTUMEN TERHADAP KUAT TARIK TAK LANGSUNG DAN KUAT TEAKAN BEBAS
}

\author{
Donny Ariawan', Slamet Budirahardjo ${ }^{2}$, Ikhwanudin ${ }^{3}$ \\ ${ }^{1}$ Fakultas Teknik, Universitas PGRI Semarang \\ donnyariawan@ymail.com \\ ${ }^{2}$ Fakultas Teknik, Universitas PGRI Semarang \\ meetz.budi@gmail.com \\ ${ }^{3}$ Fakultas Teknik, Universitas PGRI Semarang \\ ikhwan menur@yahoo.com
}

\begin{abstract}
Abstrak: Jalan beraspal merupakan salah satu prasarana transportasi utama di Indonesia yang belum sepenuhnya mencapai kondisi yang aman dan nyaman dimana sering dijumpai kondisi permukaan jalan yang tidak rata, bergelombang dan berlubang yang menyebabkan ketidaknyamanan bagi penggunanya. Kegiatan perbaikan dan pemeliharaan struktur perkerasan jalan, dalam hal ini jalan beraspal, menjadi sangat penting untuk kelangsungan kegiatan transportasi.

Pesatnya perkembangan teknologi di bidang transportasi telah melahirkan satu terobosan baru tentang teknologi penanganan kerusakan jalan yaitu dengan cara daur ulang lapis perkerasan aspal yang sudah ada. Metode daur ulang ini memiliki keuntungan antara lain dapat menghemat biaya, merupakan green technology, memiliki kualitas yang sama dengan material baru, dan menjaga geometris perkerasan karena tebal perkerasan yang sama.

Penentuan kadar air terbaik dalam campuran foam bitumen terhadap nilai kuat tarik tak langsung (ITS) serta kuat tekan bebas (UCS) untuk campuran lapis pondasi daur ulang. Dilakukan secara bertahap, dari pengujian untuk bahan penyusun campuran yaitu agregat baru, Reclaimed Asphalt Pavement (RAP), filler, aspal, dan foam bitumen. Kemudian uji terhadap campuran padat meliputi Uji Marshall, Uji Indirect Tensile Strength (ITS) dan Uji Unconfined Compressive Strength (UCS). Kadar air dan kadar foam bitumen sangat berpengaruh terhadap kuat tarik tak langsung (Indirect Tensile Strength/ITS) serta kuat tekan bebas (Unconfined Compressive Strength/UCS) dari campuran dingin daur ulang dengan foam bitumen. Nilai ITS, TSR dan UCS yang dicapai menggunakan kadar foam $2 \%$ dan kadar air optimum terbaik yang diketahui dalam penelitian sebesar $100 \%$ terhadap Kadar Air Optimum (KAO) yaitu masing- masing 301,04 kPa, 76,36\%, dan 723,49 kPa.
\end{abstract}

Kata kunci : KAO, ITS, TSR, UCS

\begin{abstract}
Paved roads is one of main the transport infrastructure in Indonesia has not fully achieve a safe and comfortable conditions which are common conditions of the road surface uneven, bumpy and potholed causing inconvenience for users. The repair and maintenance of road pavement structure, in this case a paved road, it becomes very important for the smooth operation of transport.

The rapid development of technology in the field of transport has spawned a new breakthrough on the road damage handling technology that is by recycling asphalt pavement that already exists. This recycling method has advantages such as cost savings, is a green technology, has the same quality as new material, and maintain the geometric pavement for the same pavement thickness.

The research objective was to determine the relationship between levels of foam bitumen and water content of the value of the indirect tensile strength (ITS) as well as free compressive strength (UCS) base course mix recycling with foam bitumen. This research was carried out in stages, from testing to a mixture of constituent materials, namely a new aggregate, Reclaimed Asphalt Pavement (RAP), filler, asphalt and bitumen foam. Then test against a solid mixture includes Marshall Test, Test Indirect Tensile Strength (ITS) and Test Unconfined Compressive Strength (UCS). The water content and degree of bitumen foam is very influential on indirect tensile strength (Indirect Tensile Strength / ITS) and strong free press (Unconfined Compressive Strength / UCS) of cold mix recycling with foam bitumen. Value ITS, TSR and UCS achieved by using foam content of $2 \%$ with optimum moisture content best known in the research of $100 \%$ of the Optimum Moisture Content (KAO) ie $301.04 \mathrm{kPa}$, respectively, $76.36 \%$, and $723.49 \mathrm{kPa}$.
\end{abstract}

Keywords: KAO, ITS, TSR, UCS 


\section{PENDAHULUAN}

Dalam aktivitas sehari-hari masyarakat sangat membutuhkan sarana dan prasarana transportasi. Hal tersebut didasari oleh faktor ekonomis selain itu juga faktor kemudahan, keamanan dan kenyamanan. Jalan beraspal sebagai salah satu prasarana transportasi di Indonesia belum sepenuhnya mencapai kondisi yang diharapkan, karena sering dijumpai kondisi permukaan jalan yang tidak rata, bergelombang, dan berlubang yang menyebabkan berkurangnya keamanan dan ketidaknyamanan bagi penggunanya. Oleh karena itu kegiatan perbaikan dan pemeliharaan struktur perkerasan jalan, dalam hal ini jalan beraspal, menjadi sangat penting untuk kelangsungan kegiatan transportasi.

Struktur perkerasan jalan pada prinsipnya didesain untuk memikul beban lalu lintas yang akan melaluinya sehingga tanah dasar masih mampu memikul tegangan yang timbul akibat dari beban tersebut. Perkerasan jalan beraspal tersebut dapat berupa lapisan beraspal penuh (full depth asphalt pavement) ataupun berlapis (multi layer pavement) yang terdiri dari lapisan pondasi bawah, lapisan pondasi atas, dan lapis permukaan.

Pemeliharaan kondisi jalan beraspal agar tetap dapat berfungsi dengan baik maka pada periode tertentu harus dilakukan pemeliharaan berkala. Umumnya pemeliharaan berkala tersebut dilakukan dengan cara melapis ulang (overlay). Metode penanganan dengan cara overlay yang dilakukan terus-menerus akan membentuk ketebalan jalan yang semakin tinggi, sehingga dapat mengganggu drainase, ketinggian bahu jalan dan kerb jalan serta median. Selain itu aspal, sebagai bahan pengikat untuk jalan beraspal, semakin langka keberadaannya karena aspal, yang diproduksi dari residu minyak bumi, merupakan bahan yang tidak terbarukan. Hal ini perlu diantisipasi sehingga penggunaan aspal untuk bahan pengikat lapis perkerasan jalan lebih efektif dan efisien penggunaannya.

Perkembangan teknologi dibidang transportasi yang cukup pesat telah melahirkan satu terobosan baru tentang teknologi penanganan kerusakan jalan yaitu dengan cara daur ulang lapis perkerasan aspal yang sudah ada. Metode daur ulang ini memiliki keuntungan antara lain dapat menghemat biaya, merupakan green technology, memiliki kualitas yang sama dengan material baru, dan menjaga geometris perkerasan karena tebal perkerasan tetap sama.

Ada beberapa metode daur ulang perkerasan jalan yang dikenal di Indonesia, salah satunya adalah metode daur ulang Full Depth Reclamation (FDR). Metode ini dilakukan dengan cara menggaruk lapisan hot mix dan sebagian lapis agregat di bawahnya kemudian didaur ulang dan digunakan kembali menjadi lapis pondasi yang telah distabilisasi dengan menggunakan bahan tambah/ikat untuk meningkatkan kualitasnya.

Salah satu metode daur ulang Full Depth Reclamation (FDR) adalah campuran dingin daur ulang dengan bahan ikat foam bitumen untuk lapis pondasi. Campuran dingin daur ulang dengan bahan ikat foam bitumen untuk lapis pondasi ini telah lama dilaksanakan di Indonesia, akan tetapi masih menemui kendala dimana kondisi jalan telah rusak sebelum umur rencananya tercapai.

Campuran dingin daur ulang dengan foam bitumen ini sangat dipengaruhi oleh kadar foam bitumen dan kadar air agregat campurannya sehingga dibutuhkan kontrol kualitas yang baik pada saat pelaksanaan di lapangannya. Berdasarkan permasalahan di atas maka perlu dilakukan penelitian uji laboratorium tentang "Pengaruh Kadar Air dan Kadar Foam terhadap Kuat Tarik Tak langsung dan Kuat Tekan Bebas Lapis Pondasi Daur Ulang dengan Foam Bitumen" dengan mengacu kepada Spesifikasi Khusus Bina Marga Tahun 2007 tentang Daur Ulang Campuran Beraspal Dingin Lapis Pondasi dengan Foam Bitumen (CMRFB- Base).

Dalam penelitian yang telah dilakukan dimaksudkan untuk mengetahui pengaruh kadar air dan kadar foam bitumen terhadap campuran lapis pondasi daur ulang dengan foam bitumen terhadap kuat tarik tak langsung dan kuat tekan bebasnya.

Adapun tujuan dari penelitian tersebut yaitu :

a. Mengetahui hubungan antara kadar foam bitumen dan kadar air, yang ditambahkan pada saat pencampuran agregat gabungan dan foam bitumen, dengan kuat tarik tak langsung (ITS) dari campuran lapis pondasi daur ulang dengan foam bitumen 
b. Mengetahui hubungan antara kadar foam bitumen dan kadar air, yang ditambahkan pada saat pencampuran agregat gabungan dan foam bitumen, dengan kuat tekan bebas (UCS) dari campuran lapis pondasi daur ulang dengan foam bitumen.

Campuran busa aspal adalah campuran antara agregat dan busa aspal yang dicampur secara dingin tanpa memanaskan agregat sehingga campuran ini dikategorikan sebagai Cold Mix Asphalt (CMA).

Busa aspal atau dikenal dengan foamed bitumen (expanded bitumen) adalah campuran antara gas dan cairan aspal panas. Saat volume busa aspal tinggi (kondisi dry foam) maka gelembung gas cenderung berbentuk polyhedral namun saat volumenya rendah (kondisi wet foam) gelembung gas cenderung berbentuk spherical.

Karakter busa aspal yang mengandung gelembung gas dengan film aspal yang tipis ini menyebabkan kemampuannya untuk dapat mengikat agregat pada suhu dingin. Ini adalah keunggulan busa aspal bila dibanding Hot Mix Asphalt (HMA) dimana campuran busa aspal lebih menghemat energi dan mengurangi efek polusi udara dalam implementasinya di lapangan. Hanya saja, karena umur busa aspal hanya dalam hitungan detik maka saat busa diproduksi harus langsung dicampur dengan agregat dengan menggunakan alatpencampur berkecepatan tinggi.

Foam bitumen dapat digunakan sebagai bahan penstabilisasi hampir untuk semua jenis material. Agar material yang distabilisasi memiliki workabilitas dan retained strength yang tinggi, maka penggunaan foam bitumen harus dikolaborasikan dengan penambahan filler aktif (semen/kapur) pada material yang akan distabilisasi. Walaupun menggunakan semen atau kapur, tetapi menurut Ramanujam et al. (2000) stabilisasi dengan menggunakan foam bitumen akan menghasilkan lapisan yang lebih fleksibel dibandingkan dengan bila menggunakan jenis stabilizer lainnya.

Pekerjaan stabilisasi dengan bitumen tidak mengikuti kaidah campuran beraspal, dimana pada campuran beraspal semua agregatnya harus terselimuti oleh aspal dan aspal berfungsi sebagai adesif kontak (contact adhesive). Pada pekerjaan stabilisasi dengan aspal, aspal yang digunakan sebagai stabilizer akan terdispersi dan setelah pemadatan lapisan padat yang diperoleh agak bersifat porus karena persentase rongga udara yang dihasilkan umumnya masih di atas $10 \%$. Oleh sebab itu, material yang distabilisasi dengan menggunakan bitumen hanya cocok digunakan sebagai bahan untuk lapis pondasi perkerasan jalan. (Yamin et al, 2007).

Pada prinsipnya semua perkerasan jalan akan mengalami kerusakan sepanjang umur rencananya. Hal ini disebabkan oleh faktor lingkungan dan faktor lalu lintas yang yang melaluinya. Perlu dilakukan rehabilitasi untuk memelihara kondisi jalan sehingga jalan tersebut selalu bisa digunakan oleh manusia dalam beraktivitas.

Secara umum rehabilitasi diperlukan dengan beberapa kondisi sebagai berikut :

1) Tidak memadainya kualitas kenyamanan.

2) Kerusakan perkerasan yang cukup parah.

3) Berkurangnya kekesatan antara ban dan perkerasan.

4) Perlu pemeliharaan yang ekstensif

5) Tidak memadainya user cost.

6) Tidak memadainya kapasitas struktural yang direncanakan.

7) Tidak memadainya kapasitas perkerasan untuk memikul beban lalu lintas yang direncanakan.

Ada banyak alternatif metode rehabilitasi perkerasan jalan pada saat ini, salah satunya adalah metode rehabilitasi dengan cara daur ulang perkerasan lama. Teknologi daur ulang ini telah dikembangkan sejak tahun 1915 dan mengalami perkembangan yang pesat sampai dengan saat ini.

Beberapa keuntungan dari metode rehabilitasi jalan dengan cara daur ulang perkerasan lama adalah dapat menghemat biaya, lebih ramah lingkungan karena memanfaatkan material lama, memiliki kualitas yang sama dengan material yang baru, dan tidak menambah ketinggian permukaan jalan. Salah satu metode daur ulang perkerasan 
jalan yang digunakan adalah daur ulang perkerasan lama menggunakan foam bitumen sebagai bahan ikat untuk digunakan sebagai lapis pondasi baru.

Teknologi daur ulang tersebut dikenal sebagai Campuran Dingin Daur Ulang dengan Foam Bitumen untuk Lapis Pondasi (Cold Mix Recycling by Foam Bitmen for Base, CMRFBBase). Tipikal struktur perkerasan dari rehabilitasi jalan menggunakan metode CMRFBBase. Tipikal Struktur Perkerasan Menggunakan CMRFB-Base dapat dilihat pada Gambar 1. berikut.

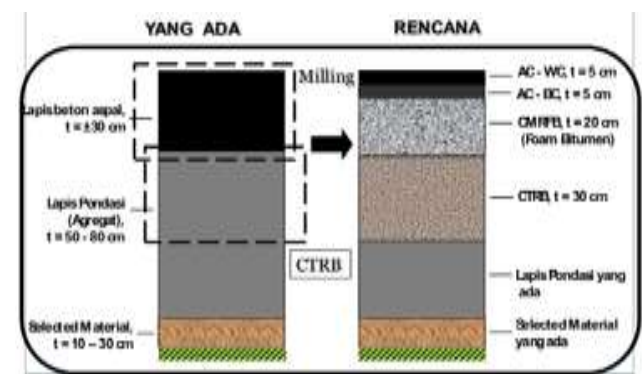

Gambar 1. Tipikal Struktur Perkerasan Menggunakan CMRFB-Base

Aspal adalah suatu bahan bentuk padat atau setengah padat berwarna hitam sampai coklat gelap, bersifat perekat (cementious) yang akan melembek dan meleleh bila dipanasi. Aspal tersusun terutama dari sebagian besar bitumen yang kesemuanya terdapat dalam bentuk padat atau setengah padat dari alam atau hasil pemurnian minyak bumi, atau merupakan campuran dari bahan bitumen dengan minyak bumi atau derivatnya (ASTM, 1994).

Foam Bitumen atau sering juga disebut foam asphalt atau expanded asphalt adalah campuran antara udara, air dan bitumen. Foam bitumen dihasilkan dengan cara menginjeksikan air ke aspal panas di dalam foaming chamber. Berikut ini adalah ilustrasi cara pembuatan foam bitumen.

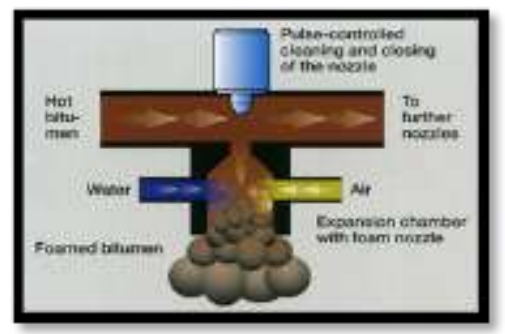

Gambar 2. Ilustrasi Cara Pembuatan Foam Bitumen

Agregat adalah partikel-partikel butiran mineral yang digunakan dengan kombinasi berbagai jenis bahan perekat membentuk massa beton atau sebagai bahan dasar jalan, backfill,dan lainnya (Atkins, 1997). Reclaimed Asphalt Pavement (RAP) adalah agregat lama yang merupakan bekas garukan atau bongkaran perkerasan beraspal yang lama kemudian didaur ulang dan digunakan kembali sebagai agregat untuk lapis pondasi baru yang distabilisasi.

Bahan pengisi (filler) yang dipergunakan dapat berupa Portland Cement Type I, bahan tersebut harus bebas dari bahan yang tidak dikehendaki dan harus sesuai dengan persyaratan SNI 15-2049-1994. Maksimum kandungan filler menggunakan semen adalah $1,5 \%$

Uji kuat tarik tidak langsung (Indirect Tensile Strength, ITS) dilakukan dengan membebani benda uji berbentuk silinder dengan beban tunggal atau beban berulang yang bekerja paralel sepanjang tegak lurus bidang diameter benda uji. Kuat tekan adalah kemampuan lapisan perkerasan untuk menahan beban yang ada secara vertikal yang dinyatakan dalam $\mathrm{kg}$ atau $\mathrm{lb}$. Besarnya muatan kendaraan yang disalurkan melalui roda kendaraan merupakan beban tekan yang diterima perkerasan. Nilai kuat tekan suatu campuran aspal beton dapat diketahui dengan Uji Kuat Tekan Bebas (Unconfined 
Compressive Strength, UCS).Pengujian ini menggunakan alat uji Marshall yang telah dimodifikasi.
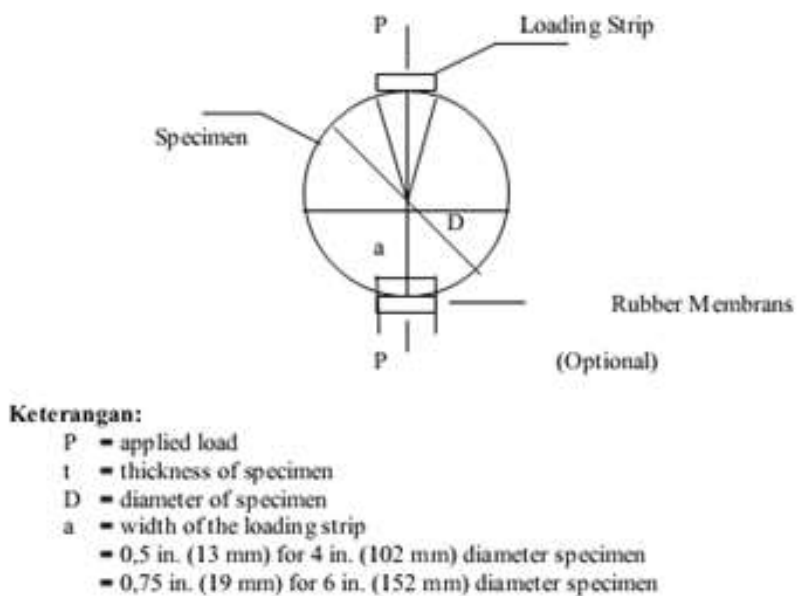

Gambar 3. Uji Kuat Tarik Tidak Langsung (ASTM,1986)

\section{METODE PENELITIAN}

Penelitian yang telah dilakukan di Laboratorium Teknik Sipil Universitas PGRI Semarang menggunakan standar pengujian yang mengacu pada Standar Nasional Indonesia (SNI), American Society for Testing and Materials (ASTM), American Association of State Highway and Transportation Official (AASHTO), dan standar atau acuan lain yang diperlukan. Dalam penelitian ini, pengujiannya dilakukan secara bertahap, terdiri dari pengujian untuk bahan penyusun campuran yaitu agregat baru, Reclaimed Asphalt Pavement (RAP), filler, aspal, dan foam bitumen. Setelah itu pengujian terhadap campuran meliputi Uji Marshall, Uji Indirect Tensile Strength (ITS) dan Uji Unconfined Compressive Strength (UCS). Secara garis besarnya tahapan penelitian ini dapat dilihat pada bagan alir penelitian pada Gambar 4, berikut ini.

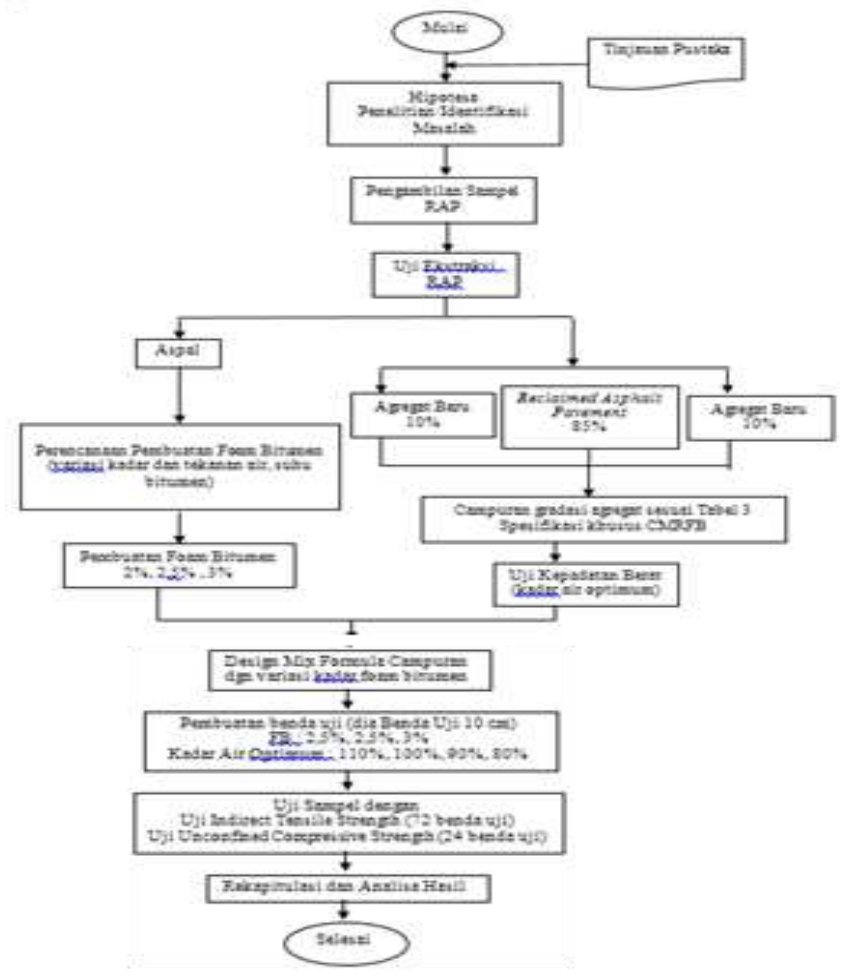

Gambar 4. Bagan Alir Penelitian 
Pemeriksaan agregat baru dilakukan apabila distribusi gradasi agregat belum memenuhi distribusi gradasi agregat yang disyaratkan sehingga perlu ditambahkan satu atau lebih fraksi agregat baru. Fraksi agregat baru yang ditambahkan harus diperiksa material properties-nya apakah memenuhi kriteria yang disyaratkan atau tidak.

Untuk perencanaan dan pembuatan foam bitumen dilakukan menggunakan alat WLB 10S dengan prosedur pengujian sebagai berikut :

a. Perencanaan pembuatan foam bitumen

Perencanaan pembuatan foam bitumen dilakukan dengan langkah-langkah sebagai berikut:

(1) Panaskan bitumen dalam ketel pada suhu $170^{\circ} \mathrm{C}$ selama min. 5 menit sebelum digunakan.

(2) Kalibrasi selang waktu penyemprotan aspal, dan tetapkan waktu yang diperlukan untuk mendapatkan foam bitumen sebanyak 500 gram.

(3) Kalibrasi penyemprotan air untuk mendapatkan kadar air di dalam bitumen (\% terhadap bitumen)

(4) Tuangkan foam bitumen ke dalam drum (yang sebelumnya sudah dipanaskan) selama waktu yang telah diperoleh pada langkah (2) untuk memperoleh bitumen seberat 500 gram. Begitu penuangan foam bitumen berhenti tekan (jalankan) stop watch.

(5) Bersamaan dengan itu ukur ketinggian yang dicapai foam bitumen di dalam drum sebagai ketinggian maksimum. Pengukuran harus menggunakan batang pengukur standar yang sudah dikalibrasi terhadap bitumen seberat 500 gram di dalam drum standar.

(6) Pada waktu volume foam bitumen menyusut sampai setengahnya, tekan (hentikan) stop watch. Catat waktunya sebagai Umur Paruh (Half Life).

(7) Ulangi langkah (3) sampai dengan (6) dengan paling sedikit 3 macam kadar air (biasanya 2\%, 3\% dan 4\% terhadap berat bitumen)

(8) Gambarkan di dalam grafik, hubungan antara nilai pengembangan dan paruh umur terhadap variasi kadar air.

(9) Tentukan kadar air optimum untuk pembuatan foam bitumen.

Tabel 1. Standar Pengujian Agregat Kasar Baru

\begin{tabular}{|l|c|}
\hline \multicolumn{1}{|c|}{ Pengujian } & Standar \\
\hline Abrasi dengan Mesin Los Angeles & SNI 03-2417-1991 \\
\hline Kelekatan Agregat terhadap Aspal & SNI 03-2439-1991 \\
\cline { 1 - 2 } Angularitas (kedalaman dari permukaan $<10 \mathrm{~cm}$ ) & $\begin{array}{c}\text { DoT's Pennsylvania Test } \\
\text { Method, PTM No.621 }\end{array}$ \\
\cline { 1 - 2 } Angularitas (kedalaman dari permukaan $\geq 10 \mathrm{~cm}$ ) & ASTM D-4791 \\
\hline Partikel Pipih dan Lonjong $\left(^{*}\right)$ & SNI 03-4142-1996 \\
\hline Material Lolos Saringan No. 200 &
\end{tabular}

Tabel 2. Standar Pengujian Agregat Halus Baru

\begin{tabular}{|l|c|}
\hline \multicolumn{1}{|c|}{ Pengujian } & Standar \\
\hline Nilai Setara Pasir & SNI 03-2417-1991 \\
\hline Angularitas (kedalaman dari permukaan $<10 \mathrm{~cm}$ ) & SNI 03-6877-2002 \\
\hline Angularitas (kedalaman dari permukaan $\geq 10 \mathrm{~cm}$ ) & \\
\hline
\end{tabular}

Tabel 3.Prosedur Pengujian Standar Untuk Aspal Pen 60/70

\begin{tabular}{|c|l|c|}
\hline No & \multicolumn{1}{|c|}{ Uji } & Metode Tes \\
\hline 1 & Penetrasi & SNI 06-2456-1991 \\
\hline 2 & Titik Lembek & SNI 03-2434-1991 \\
\hline 3 & Titik Nyala & SNI 03-2433-1991 \\
\hline 4 & Kehilangan Berat & SNI 03-2440-1991 \\
\hline 5 & Kelarutan Trichlor Ethylene & SNI 06-2456-1991 \\
\hline 6 & Daktilitas & SNI 03-2432-1991 \\
\hline
\end{tabular}




\begin{tabular}{|c|l|l|}
\hline 7 & Penetrasi setelah kehilangan berat & SNI 03-2456-1991 \\
\hline 8 & Viskositas aspal & SNI 03-6721-2002 \\
\hline 9 & Berat Jenis & SNI 06-2441-1991 \\
\hline 10 & Perencanaan \& Pembuatan foam bitumen & Wirtgen WLB 10 S \\
\hline
\end{tabular}

b. Pembuatan foam bitumen

Buat foam bitumen dengan suhu dan tekanan aspal serta tekanan dan kadar air seperti yang diperoleh dari percobaan diatas untuk pembuatan campuran RAP, agregat baru dan semen.

Perancangan campuran dibagi dalam beberapa langkah pengujian yang pertama adalah pengujian kepadatan untuk menentukan kadar air optimum campuran agregat baru, RAP dan filler. Kemudian dilanjutkan dengan pengujian untuk menentukan kadar foam bitumen optimum di dalam campuran RAP, agregat baru dan filler pada kadar air optimum serta dilanjutkan dengan pengujian untuk penentuan kekuatan. Tabel berikut menunjukkan pengujian terhadap campuran dan standar atau prosedur yang digunakan.

Proses pencampuran ini dilakukan dalam beberapa tahapan yaitu:

a. Penentuan Jumlah Foam Bitumen

Penentuan jumlah foam bitumen yang ditambahkan dengan rumus sebagai berikut:

$\mathrm{M}_{\mathrm{FB}}=\left(\frac{\mathrm{FB}_{\mathrm{add}}}{100}\right) \times\left(\mathrm{M}_{\text {contoh uji }}+\mathrm{M}_{\text {semen }}\right)$

dimana:

$\mathrm{M}_{\mathrm{FB}} \quad$ = Berat foam bitumen yang dibutuhkan (gram)

$\mathrm{FB}_{\text {add }} \quad=$ Kadar foam bitumen (\%)

$\mathrm{M}_{\text {contoh uji }} \quad$ = Berat kering contoh uji (gram)

$\mathrm{M}_{\text {semen }} \quad$ = Berat semen yang ditambahkan (gram)

b. Pengaturan Waktu

Pengaturan waktu pada alat pembuatan foam bitumen di laboratorium sesuai dengan rumus berikut:

$\mathrm{T}=$ faktor $\mathrm{x}\left(\mathrm{M}_{\mathrm{FB}}+\mathrm{Q}_{\mathrm{FB}}\right)$

dimana:

$\mathrm{T}=$ = Pengaturan waktu pada alat (detik)

$\mathrm{M}_{\mathrm{FB}} \quad$ = Berat foam bitumendibutuhkan (gram)

$\mathrm{Q}_{\mathrm{FB}} \quad=$ Aliran foam bitumen pada alat pembuat (gram/detik)

faktor $\quad=$ Kompensasi kehilangan foam bitumen pada alat pencampur.

Faktor ini sebesar 1.1.

c. Pencampuran dengan Foam Bitumen

Pencampuran dengan foam bitumen dilakukan sesuai dengan langkah-langkah berikut ini:

(1) Atur alat pencampur tepat di bawah penyemprot alat foam bitumen supaya foam dapat dituangkan langsung ke dalam alat pencampur.

(2) Segera lakukan "pencampuran kering" selama minimum 10 detik sebelum foam yang diperlukan dituang ke dalam alat pencampur. Setelah foam bitumen dituangkan maka dilakukan "pencampuran basah" selama 30 detik.

(3) Tambahkan air ke campuran tersebut sehingga campuran tersebut memiliki kadar air optimum dan campur hingga homogen. Kuantitas air yang ditambahkan menggunakan rumus sebagai berikut: 
$M_{\text {plus }}=\frac{\left(w_{\text {omc }}-w_{\text {contoh uji }}\right)}{100} \times\left(M_{\text {contoh uji }}+M_{\text {semen }}\right)$

dimana:

$\mathrm{M}_{\text {plus }} \quad$ = Berat air yang ditambahkan (gram)

$\mathrm{w}_{\mathrm{omc}} \quad=$ kadar air optimum (\% berat)

$\mathrm{w}_{\text {contoh uji }} \quad=$ Kadar air contoh uji yang disiapkan (\% berat)

$\mathrm{M}_{\text {contoh uji }} \quad=$ Berat kering contoh uji (gram)

$\mathrm{M}_{\text {semen }} \quad$ = Berat semen yang ditambahkan (gram)

d. Perawatan Campuran

Tuangkan campuran setelah selesai dicampur dengan foam bitumen ke dalam wadah dan segera dibungkus dengan pembungkus yang kedap sehingga kelembaban campuran dapat dipertahankan.

Adapun langkah pembuatan benda uji tersebut adalah sebagai berikut:

a. Pembuatan Benda Uji Kuat Tarik Tak Langsung (ITS)

1. Pembuatan

- Siapkan mold ukuran $10 \mathrm{~cm}$ dan alat pemadat Marshall

- Siapkan contoh uji berat cukup untuk tinggi padat benda uji $63,5 \mathrm{~mm} \pm 1,5 \mathrm{~mm}$ (sekitar 1.150 gram)

- Masukkan campuran ke dalam mold, kemudian ditusuk-tusuk dengan spatula dan dipadatkan sesuai dengan prosedur pembuatan benda uji Marshall (RSNI M-012003).

- Padatkan campuran dengan pemadatan Marshall 2 x 75 tumbukan.

- Setelah selesai, keluarkan benda uji dengan menggunakan extruder.

2. Perawatan

- Letakkan benda uji pada nampan dan masukkan ke dalam oven selama 3×24 jam pada suhu $40^{\circ} \mathrm{C}$. Setelah itu keluarkan benda uji dan dinginkan pada suhu ruangan (untuk ITS kering).

- Rendam benda uji pada wadah selama 24 jam pada suhu $25^{\circ} \mathrm{C}$ (untuk ITS rendam).

b. Penentuan Berat Isi Curah

Berat Isi Curah dihitung dengan rumus berikut:

$\mathrm{BD}=\frac{\left(4 \times \mathrm{M}_{\text {bricket }}\right)}{\left(\pi \times \mathrm{h} \times \mathrm{d}^{2}\right)}$

dimana:

BD $\quad=$ Berat isi curah $\left(\mathrm{kg} / \mathrm{m}^{3}\right)$

$\mathrm{M}_{\text {bricket }} \quad$ = Berat bricket (gram)

$\mathrm{h} \quad=$ Rata-rata tinggi bricket $(\mathrm{cm})$

$\mathrm{d}=$ Diameter bricket $(\mathrm{cm})$

c. Penentuan Kadar Foam Bitumen Optimum

Penentuan kadar foam bitumen optimum dilakukan dengan uji Indirect Tensile Strength (ITS) pada kondisi kering dan rendaman. Hasil pengujian pada variasi kadar foam bitumen tersebut ditampilkan dengan grafik. Kadar foam bitumen yang paling baik memenuhi kriteria dianggap sebagai kadar foam bitumen optimum.

Hubungan nilai ITS kering dan rendaman terhadap kadar foam bitumen yang sesuai ditampilkan pada grafik. Kadar foam bitumen yang memenuhi karakteristik campuran merupakan kadar foam bitumen optimum yang dipilih.

d. Penentuan Kekuatan 
- Lakukan pengujian Indirect Tensile Strength (ITS) dengan kecepatan deformasi $50,8 \mathrm{~mm} /$ menit pada axis diameter sesuai dengan ASTM D 4123-82.

- Setelah benda uji runtuh, ambil contoh sekitar $1 \mathrm{~kg}$ untuk menentukan kadar air contoh. Kadar air digunakan untuk menghitung berat isi kering benda uji

- Hitung Indirect Tensile Strength (ITS) dengan rumus:

ITS $=\left[\frac{2 \times P}{\pi \times h \times d}\right] \times 10000$

dimana:

ITS $\quad=$ Indirect Tensile Strength $(\mathrm{kPa})$

$\mathrm{P} \quad=$ Beban maksimum yang diperlukan $(\mathrm{kN})$

$\mathrm{h} \quad \quad=$ Tinggi (tebal) benda uji rata rata $(\mathrm{cm})$

$\mathrm{d}=$ Diameter benda uji $(\mathrm{cm})$

- Untuk menentukan ITS rendaman, letakkan (rendam) benda uji pada air dengan suhu $25^{\circ} \mathrm{C} \pm 1^{\circ} \mathrm{C}$ selama 24 jam. Angkat benda uji dari rendaman, keringkan permukaannya dan lakukan pengujian ITS sesuai tahap yang telah diuraikan di atas.

- Hitung Tensile Strength Retained (TSR) yang merupakan hubungan antara ITS tidak direndam dan ITS rendaman benda uji yang dinyatakan sebagai persen.

$T S R=\frac{I T S_{\text {rendaman }}}{I T S_{\text {tanpa direndam }}} \times 100 \%$

dimana:

TSR $\quad=$ Tensile Strength Retained (\%)

ITS $_{\text {rendaman }}=$ Nilai ITS rendaman $(\mathrm{kPa})$

$\mathrm{ITS}_{\text {kering }}=$ Nilai ITS kering $(\mathrm{kPa})$

e. Pembuatan Benda Uji Kuat Tekan Bebas (UCS)

Pembuatan

- Siapkan mold dan alat pemadatnya.

- Untuk setiap pembuatan benda uji, masukkan campuran kedalam mold tangkup (yang dapat dibuka = splitmould), kemudian tusuk-tusuk dengan spatula dan padatkan sesuai prosedur kepadatan berat sesuai SNI 03-1743-1989.

- Ambil kurang lebih $1 \mathrm{~kg}$ dari contoh uji setelah dipadatkan dari briket pertama dan ketiga dan keringkan (dioven) sampai berat konstan. Tentukan kadar air menggunakan persamaan:

$\mathrm{w}_{\text {mould }}=\frac{\left(\mathrm{M}_{\text {basah }}-\mathrm{M}_{\text {kering udara }}\right)}{\mathrm{M}_{\text {kering udara }}} \times 100 \%$

dimana :

$\mathrm{W}_{\text {mould }} \quad=$ Kadar air benda uji (\% berat)

$\mathrm{M}_{\text {basah }} \quad$ = Berat contoh uji basah (gram)

$\mathrm{M}_{\text {kering udara }}=$ Berat contoh uji kering (gram)

- Padatkan benda uji menggunakan mold tangkup (yang dapat dibuka = split mould) diameter $150 \mathrm{~mm}$ sesuai prosedur pemadatan AASHTO T 180 (5 lapis tebal sekitar $25 \mathrm{~mm}, 55$ tumbukan setiap lapis menggunakan pemadat seberat 4,536 kg pada ketinggian $457 \mathrm{~mm}$ ).

- Ratakan kelebihan material pada mold. 
- Keluarkan benda uji dari mold kemudian letakkan pada nampan dan diamkan pada suhu ruangan selama 24 jam atau sampai kira-kira kadar air telah berkurang sebesar minimum $50 \%$ dari kadar air optimum.

\section{Perawatan}

- Masukkan masing-masing benda uji pada kantong plastik (yang besarnya minimum 2 kali volume benda uji) tertutup rapat dan masukkan ke oven pada suhu $40{ }^{\circ} \mathrm{C}$ selama 48 jam.

- Keluarkan benda uji setelah 48 jam dari oven dan keluarkan dari kantong plastik secara hati-hati sehingga tiak ada air di plastik mengenai benda uji, kemudian diamkan hingga dingin pada suhu ruangan.

- Setelah dingin tentukan berat benda uji dan hitung Berat Isi benda uji (bulk density) seperti rumus berikut:

$$
\mathrm{BD}_{\text {mould }}=\frac{\mathrm{M}_{\text {briket }}}{\mathrm{Vol}} \times 1000
$$

dimana:

$$
\begin{array}{ll}
\mathrm{BD}_{\text {mould }} & =\text { Berat Isi benda uji }\left(\mathrm{kg} / \mathrm{m}^{3}\right) \\
\mathrm{M}_{\text {briket }} & =\text { berat benda uji }(\mathrm{gram}) \\
\text { Vol } & =\text { volume benda uji }\left(\mathrm{cm}^{3}\right)
\end{array}
$$

\section{Penentuan Kekuatan}

- Pengujian dilakukan dengan mengukur beban maksimum pada saat benda uji runtuh dengan kecepatan pembebanan $140 \mathrm{kPa} / \mathrm{set}$ (153 kN/menit).

- Setelah benda uji runtuh ambil contoh sekitar $1 \mathrm{~kg}$ untuk menentukan kadar air contoh. Kadar air tersebut digunakan untuk menghitung berat isi kering benda uji.

- Perhitungan UCS sesuai rumus berikut :

$$
\text { UCS }=\left[\frac{4 \times P}{\pi \times d^{2}}\right] \times 10000
$$

dimana:

$$
\begin{array}{ll}
\text { UCS } & =\text { Unconfined Compressive Strength }(\mathrm{kPa}) \\
\mathrm{P} & =\text { Beban maksimum yang diperlukan }(\mathrm{kN}) \\
\mathrm{d} & =\text { Diameter benda uji }(\mathrm{cm})
\end{array}
$$

\section{Penentuan Kepadatan Kering}

Dengan nilai kadar air yang diambil setelah pengujian, tentukan kepadatan kering dengan rumus sebagai berikut:

$$
\mathrm{DD}=\left[\frac{\mathrm{M}_{\text {bricket }}}{\text { Vol }}\right] \times\left\{\frac{100}{\left(w_{\text {bricket }}+100\right)}\right\}
$$

dimana:

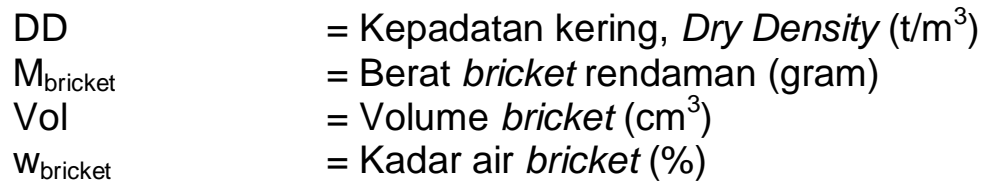

\section{HASIL DAN PEMBAHASAN}

Setelah gradasi agregat campuran telah memenuhi spesifikasi kemudian dilakukan pengujian kepadatan berat, menggunakan metode Proctor Modified, untuk mengetahui berat 
kering maksimum $(\gamma d)$ dan kadar air optimum dari campuran agregat gabungan tersebut. Hasil dari pengujian kepadatan berat tersebut tampak pada Tabel berikut.

Tabel 1. Hasil Uji Kepadatan Berat Agregat Gabungan

\begin{tabular}{|c|l|c|c|c|c|}
\hline No & \multicolumn{1}{|c|}{ Jenis Pengujian } & Hasil Uji & Syarat & Metode Pengujian & Satuan \\
\hline 1 & Berat Kering Maksimum $(\gamma \mathrm{d})$ & 2.03 & & SNI 03-1742-1989 & $\mathrm{g} / \mathrm{cm}^{3}$ \\
\hline 2 & Kadar Air Optimum & 4.03 & & SNI 03-1742-1989 & $\%$ \\
\hline
\end{tabular}

Hasil pengujian kuat tarik tak langsung sampel uji dengan kadar foam bitumen $2 \%$, dan kadar air $80 \%$ terhadap KAO adalah sebagai berikut:

Tabel 6. Hasil Uji ITS untuk 2\% FB - Kadar Air 80\% thd KAO

\begin{tabular}{|c|c|c|c|c|c|c|c|c|c|c|c|}
\hline & & & & \multirow{3}{*}{\begin{tabular}{|c|} 
VOLUME \\
$\left(\mathrm{cm}^{3}\right)$
\end{tabular}} & \multirow{3}{*}{\begin{tabular}{|c|}
$\begin{array}{c}\text { BERAT JENIS } \\
\text { BULK }\end{array}$ \\
gram/cc \\
\end{tabular}} & \multirow{3}{*}{$\begin{array}{c}\begin{array}{c}\text { PEMBACAAN } \\
\text { ARLOJI }\end{array} \\
\mathrm{kg}\end{array}$} & \multirow{3}{*}{$\begin{array}{c}\text { BEBAN MAX } \\
(\mathrm{KN})\end{array}$} & & & \multicolumn{2}{|c|}{$80 \%$ KAO - $2 \%$ FOAM } \\
\hline \multicolumn{2}{|c|}{ NO.CONTOH } & \multicolumn{2}{|c|}{ BERAT CONTOH (GRAM) } & & & & & \multicolumn{2}{|c|}{ CONTOH UJ (cm) } & \multirow{2}{*}{$\frac{\text { ITS }}{(\mathrm{kPa})}$} & \multirow{2}{*}{$\begin{array}{l}\text { TSR } \\
(\%)\end{array}$} \\
\hline \multirow{2}{*}{\multicolumn{2}{|c|}{ A }} & UDARA & AIR & & & & & TINGGI & DIAMETER & & \\
\hline & & B & C & $D=B-C$ & $E=B / D$ & $\mathrm{~F}$ & 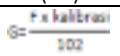 & $\mathrm{H}$ & I & $\ln \frac{2 \times 6 \times 10000}{501421}$ & 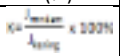 \\
\hline 1 & , kering & 1083.4 & & & & 26.00 & 3.09 & 6.60 & 10.20 & 291.92 & \multirow{12}{*}{75.41} \\
\hline 2 & , kering & 1080.0 & & & & 25.00 & 2.97 & 6.50 & 10.20 & 285.01 & \\
\hline 3 & , kering & 1071.6 & & & & 25.00 & 2.97 & 6.40 & 10.20 & 289.46 & \\
\hline & & & & & & & & & & & \\
\hline & & & & & & & & & & & \\
\hline \multicolumn{2}{|c|}{ RATA - RATA } & & & & & & & & & 288.79 & \\
\hline 1 & , rendam & 1090.0 & 611.0 & 4779.0 & 2.276 & 19.00 & 2.25 & 6.50 & 10.20 & 216.61 & \\
\hline 2 & , rendam & 1085.8 & 612.8 & 473.0 & 2.296 & 18.00 & 2.14 & 6.50 & 10.20 & 205.21 & \\
\hline \multirow[t]{3}{*}{3} & , rendam & 1077.7 & 612.0 & 465.7 & 2.314 & 20.00 & 2.37 & 6.40 & 10.20 & 231.57 & \\
\hline & & & & & & & & & & & \\
\hline & & & & & & & & & & & \\
\hline \multicolumn{2}{|c|}{ RATA - RATA } & & & & & & & & & 217.79 & \\
\hline & & & & & & & & & & & \\
\hline \multicolumn{2}{|c|}{ CATATAN : } & \multicolumn{5}{|c|}{ KONDISI KERING, OVEN SELAMA 72 JAM $\left(3 \times 24\right.$ JAM), SUHU $40^{\circ} \mathrm{C}$} & & & & & \\
\hline & & \multicolumn{5}{|c|}{ KONDISI RENDAMAN (BASAH), RENDAM SELAMA $24 \mathrm{JAM}$, SUHU $25^{\circ} \mathrm{C}$} & & & & & \\
\hline \multicolumn{2}{|c|}{ SYARAT: } & \multirow{2}{*}{\multicolumn{2}{|c|}{ ITS, MINIMUM $300 \mathrm{kPa}$}} & & & & & & & & \\
\hline & & & & & & & & & & & \\
\hline
\end{tabular}

Sumber: Hasil Uji, 2016

Hasil uji menunjukkan nilai ITS kering maksimum dan ITS rendam maksimum masingmasing adalah $291.92 \mathrm{kPa}$ dan $231.57 \mathrm{kPa}$. Sedangkan nilai ITS kering dan ITS rendam rata-rata masing-masing adalah $288.79 \mathrm{kPa}$ dan $217.79 \mathrm{kPa}$.Adapun nilai Tensile Strength Retained (TSR) dari hasil uji tersebut adalah $75.41 \%$.

Hasil pengujian kuat tarik tak langsung sampel uji dengan kadar foam bitumen $2 \%$, dan kadar air $90 \%$ terhadap KAO adalah sebagai berikut:

Tabel 7. Hasil Uji ITS untuk $2 \%$ FB - Kadar Air $90 \%$ thd KAO

\begin{tabular}{|c|c|c|c|c|c|c|c|c|c|c|c|}
\hline & & & & \multirow{3}{*}{\begin{tabular}{|c|} 
VOLUME \\
$\left(\mathrm{cm}^{3}\right)$ \\
\end{tabular}} & \multirow{3}{*}{$\begin{array}{c}\text { BERAT JENIS } \\
\text { BULK } \\
\text { gram/cc } \\
\end{array}$} & \multirow{3}{*}{$\begin{array}{c}\begin{array}{c}\text { PEMBACAAN } \\
\text { ARLOJI }\end{array} \\
\mathrm{kg} \\
\end{array}$} & \multirow{3}{*}{\begin{tabular}{|c|} 
BEBAN MAX \\
$(\mathrm{KN})$ \\
\end{tabular}} & & & \multicolumn{2}{|c|}{$90 \%$ KAO - $2 \%$ FOAM } \\
\hline \multicolumn{2}{|c|}{ NO.CONTOH } & \multicolumn{2}{|c|}{ BERAT CONTOH (GRAM) } & & & & & \multicolumn{2}{|c|}{ CONTOH UJI (cm) } & \multirow{2}{*}{$\begin{array}{c}\text { ITS } \\
(\mathrm{kPa}) \\
\end{array}$} & \multirow{2}{*}{$\begin{array}{c}\text { TSR } \\
(\%)\end{array}$} \\
\hline \multirow{2}{*}{\multicolumn{2}{|c|}{ A }} & UDARA & AIR & & & & & TINGGI & DIAMETER & & \\
\hline & & B & c & $D=B-C$ & $E=B / D$ & $\mathrm{~F}$ & 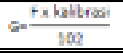 & $\mathrm{H}$ & 1 & 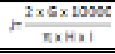 & 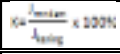 \\
\hline 1 & , kering & 1083.9 & & & & 24.00 & 2.85 & 6.40 & 10.20 & 277.88 & \multirow{12}{*}{73.52} \\
\hline 2 & , kering & 1073.6 & & & & 24.00 & 2.85 & 6.50 & 10.20 & 273.61 & \\
\hline 3 & , kering & 1082.1 & & & & 23.00 & 2.73 & 6.40 & 10.20 & 266.30 & \\
\hline & & & & & & & & & & & \\
\hline & & & & & & & & & & & \\
\hline \multicolumn{2}{|c|}{ RATA - RATA } & & & & & & & & & 272.60 & \\
\hline 1 & , rendam & 1080.7 & 613.6 & 467.1 & 2.31 & 18.00 & 2.14 & 6.50 & 10.20 & 205.21 & \\
\hline 2 & , rendam & 1078.8 & 609.3 & 469.5 & 2.30 & 18.00 & 2.14 & 6.50 & 10.20 & 205.21 & \\
\hline \multirow[t]{3}{*}{3} & , rendam & 1076.3 & 607.7 & 468.6 & 2.30 & 17.00 & 2.02 & 6.60 & 10.20 & 190.87 & \\
\hline & & & & & & & & & & & \\
\hline & & & & & & & & & & & \\
\hline \multicolumn{2}{|c|}{ RATA - RATA } & & & & & & & & & 200.43 & \\
\hline & & & & & & & & & & & \\
\hline \multicolumn{2}{|c|}{ CATATAN : } & \multicolumn{5}{|c|}{ KONDISI KERING, OVEN SELAMA 72 JAM ( $3 \times 24$ JAM), SUHU $400^{\circ} \mathrm{C}$} & & & & & \\
\hline & & KONDISI REN & IAN (BASAH & ), RENDAM SE & ELAMA 24 JAM, S & SUHU $25^{\circ} \mathrm{C}$ & & & & & \\
\hline \multirow{2}{*}{\multicolumn{2}{|c|}{ SYARAT: }} & \multirow{2}{*}{\multicolumn{2}{|c|}{$\begin{array}{l}\text { ITS, MINIMUM } 300 \mathrm{kPa} \\
\text { TSR, MINIMUM } 80 \%\end{array}$}} & & & & & & & & \\
\hline & & & & & & & & & & & \\
\hline
\end{tabular}

Sumber: Hasil Uji, 2016 
Hasil uji menunjukkan nilai ITS kering maksimum dan ITS rendam maksimum masingmasing adalah $277.88 \mathrm{kPa}$ dan $205.21 \mathrm{kPa}$. Sedangkan nilai ITS kering dan ITS rendam rata-rata masing-masing adalah $272.60 \mathrm{kPa}$ dan $200.43 \mathrm{kPa}$.Adapun nilai Tensile Strength Retained (TSR) dari hasil uji tersebut adalah $73.52 \%$.

Hasil pengujian kuat tarik tak langsung sampel uji dengan kadar foam bitumen $2 \%$, dan kadar air $100 \%$ terhadap KAO adalah sebagai berikut:

Tabel 8. Hasil Uji ITS untuk 2\% FB - Kadar Air 100\% thd KAO

\begin{tabular}{|c|c|c|c|c|c|c|c|c|c|c|c|}
\hline & & & & \multirow{3}{*}{$\begin{array}{c}\text { VOLUME } \\
\left(\mathrm{cm}^{3}\right)\end{array}$} & \multirow{3}{*}{$\begin{array}{c}\text { BERAT JENIS } \\
\text { BULK } \\
\text { gram/cc } \\
\end{array}$} & \multirow{3}{*}{$\begin{array}{c}\begin{array}{c}\text { PEMBACAAN } \\
\text { ARLOJI }\end{array} \\
\mathrm{kg} \\
\end{array}$} & \multirow{3}{*}{$\begin{array}{c}\text { BEBAN MAX } \\
\text { (KN) }\end{array}$} & \multirow{2}{*}{\multicolumn{2}{|c|}{ CONTOH UJ (cm) }} & \multicolumn{2}{|c|}{$100 \%$ KAO - $2 \%$ FOAM } \\
\hline \multicolumn{2}{|c|}{ NO.CONTOH } & \multicolumn{2}{|c|}{ BERAT CONTOH (GRAM) } & & & & & & & \multirow{2}{*}{$\begin{array}{c}\text { ITS } \\
(\mathrm{kPa})\end{array}$} & \multirow{3}{*}{ 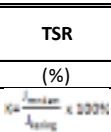 } \\
\hline \multirow{2}{*}{\multicolumn{2}{|c|}{ A }} & UDARA & AIR & & & & & TINGGI & DIAMETER & & \\
\hline & & B & C & $D=B-C$ & $E=B / D$ & $\mathrm{~F}$ & 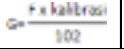 & H & 1 & $r \frac{2 x G \times 00000}{\pi x+10}$ & \\
\hline 1 & kering & 1068.9 & & & & 25.00 & 2.97 & 6.50 & 10.20 & 285.01 & \multirow{11}{*}{76.36} \\
\hline 2 & kering & 1086.4 & & & & 24.00 & 2.85 & 6.50 & 10.20 & 273.61 & \\
\hline 3 & kering & 1071.0 & & & & 26.00 & 3.09 & 6.40 & 10.20 & 301.04 & \\
\hline & & & & & & & & & & & \\
\hline \multicolumn{2}{|c|}{ RATA - RATA } & & & & & & & & & 286.55 & \\
\hline 1 & rendam & 1076.2 & 610.3 & 465.9 & 2.31 & 19.00 & 2.25 & 6.40 & 10.20 & 219.99 & \\
\hline 2 & rendam & 1063.8 & 611.3 & 452.5 & 2.35 & 20.00 & 2.37 & 6.50 & 10.20 & 228.01 & \\
\hline \multirow[t]{3}{*}{3} & rendam & 1081.2 & 617.3 & 463.9 & 2.33 & 18.00 & 2.14 & 6.40 & 10.20 & 208.41 & \\
\hline & & & & & & & & & & & \\
\hline & & & & & & & & & & & \\
\hline \multicolumn{2}{|c|}{ RATA - RATA } & & & & & & & & & 218.80 & \\
\hline & & & & & & & & & & & \\
\hline \multicolumn{2}{|c|}{ CATATAN : } & \multicolumn{5}{|c|}{ KONDISI KERING, OVEN SELAMA 72 JAM ( $3 \times 24$ JAM), SUHU $40^{\circ} \mathrm{C}$} & & & & & \\
\hline & & \multicolumn{5}{|c|}{ KONDISI RENDAMAN (BASAH), RENDAM SELAMA $24 \mathrm{JAM}$, SUHU $25^{\circ} \mathrm{C}$} & & & & & \\
\hline \multirow{2}{*}{\multicolumn{2}{|c|}{ SYARAT: }} & \multirow{2}{*}{\multicolumn{2}{|c|}{$\begin{array}{l}\text { ITS, MINIMUM } 300 \mathrm{kPa} \\
\text { TSR, MINIMUM } 80 \%\end{array}$}} & & & & & & & & \\
\hline & & & & & & & & & & & \\
\hline
\end{tabular}

Sumber: Hasil Uji, 2016

Hasil uji menunjukkan nilai ITS kering maksimum dan ITS rendam maksimum masingmasing adalah $301.04 \mathrm{kPa}$ dan $228.01 \mathrm{kPa}$. Sedangkan nilai ITS kering dan ITS rendam rata-rata masing-masing adalah $286.55 \mathrm{kPa}$ dan $218.80 \mathrm{kPa}$.Adapun nilai Tensile Strength Retained (TSR) dari hasil uji tersebut adalah $76.36 \%$.

Hasil pengujian kuat tarik tak langsung sampel uji dengan kadar foam bitumen $2 \%$, dan kadar air $110 \%$ terhadap KAO adalah sebagai berikut:

Tabel 9. Hasil Uji ITS untuk 2\% FB - Kadar Air 110\% thd KAO

\begin{tabular}{|c|c|c|c|c|c|c|c|c|c|c|c|}
\hline & & & & \multirow{3}{*}{\begin{tabular}{|c|} 
VOLUME \\
$\left(\mathrm{cm}^{3}\right)$ \\
\end{tabular}} & \multirow{3}{*}{\begin{tabular}{|c|}
$\begin{array}{c}\text { BERAT JENIS } \\
\text { BULK }\end{array}$ \\
gram/cc \\
\end{tabular}} & \multirow{3}{*}{\begin{tabular}{|c|}
$\begin{array}{c}\text { PEMBACAAN } \\
\text { ARLOJI }\end{array}$ \\
$\mathrm{kg}$ \\
\end{tabular}} & \multirow{3}{*}{$\begin{array}{c}\text { BEBAN MAX } \\
(\mathrm{KN})\end{array}$} & & & \multicolumn{2}{|c|}{$110 \%$ KAO $-2 \%$ FOAM } \\
\hline \multicolumn{2}{|c|}{ NO.CONTOH } & \multicolumn{2}{|c|}{ BERAT CONTOH (GRAM) } & & & & & \multicolumn{2}{|c|}{ CONTOH UJ (cm) } & \multirow{2}{*}{$\begin{array}{c}\text { ITS } \\
(\mathrm{kPa}) \\
\end{array}$} & \multirow{3}{*}{ 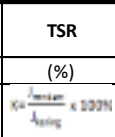 } \\
\hline \multirow{2}{*}{\multicolumn{2}{|c|}{ A }} & UDARA & AIR & & & & & TINGGI & DIAMETER & & \\
\hline & & B & C & $D=B-C$ & $E=B / D$ & $\mathrm{~F}$ & $\theta=\frac{\text { ts biltriain }}{100}$ & $\mathrm{H}$ & 1 & $\frac{2 \times 6 \times 10000}{5 \times 1+1}$ & \\
\hline 1 & , kering & 1073.2 & & & & 25 & 2.97 & 6.50 & 10.20 & 284.86 & \multirow{12}{*}{65.43} \\
\hline 2 & , kering & 1083.0 & & & & 27 & 3.20 & 6.30 & 10.20 & 317.42 & \\
\hline 3 & , kering & 1077.5 & & & & 27 & 3.20 & 6.20 & 10.20 & 322.54 & \\
\hline & & & & & & & & & & & \\
\hline & & & & & & & & & & & \\
\hline \multicolumn{2}{|c|}{ RATA - RATA } & & & & & & & & & 308.27 & \\
\hline 1 & , rendam & 1088.6 & 617.1 & 471.5 & 2.31 & 17 & 2.02 & 6.40 & 10.20 & 196.73 & \\
\hline 2 & , rendam & 1067.9 & 609.8 & 458.1 & 2.33 & 17 & 2.02 & 6.40 & 10.20 & 196.73 & \\
\hline \multirow[t]{3}{*}{3} & , rendam & 1083.2 & 616.6 & 466.6 & 2.32 & 18 & 2.14 & 6.30 & 10.20 & 211.61 & \\
\hline & & & & & & & & & & & \\
\hline \multirow{2}{*}{\multicolumn{2}{|c|}{ RATA - RATA }} & & & & & & & & & & \\
\hline & & & & & & & & & & 201.69 & \\
\hline & & & & & & & & & & & \\
\hline \multicolumn{2}{|c|}{ CATATAN : } & \multicolumn{5}{|c|}{ KONDISI KERING, OVEN SELAMA 72 JAM ( $3 \times 24$ JAM), SUHU $40^{\circ} \mathrm{C}$} & & & & & \\
\hline & & \multicolumn{5}{|c|}{ KONDISI RENDAMAN (BASAH), RENDAM SELAMA 24 JAM, SUHU $25^{\circ} \mathrm{C}$} & & & & & \\
\hline \multirow{2}{*}{\multicolumn{2}{|c|}{ SYARAT: }} & \multirow{2}{*}{\multicolumn{2}{|c|}{$\begin{array}{l}\text { ITS, MINIMUM } 300 \mathrm{kPa} \\
\text { TSR, MINIMUM 80\% }\end{array}$}} & & & & & & & & \\
\hline & & & & & & & & & & & \\
\hline
\end{tabular}

Sumber: Hasil Uji, 2016

Hasil uji menunjukkan nilai ITS kering maksimum dan ITS rendam maksimum masingmasing adalah $322.54 \mathrm{kPa}$ dan $211.61 \mathrm{kPa}$. Sedangkan nilai ITS kering dan ITS rendam rata-rata masing-masing adalah $308.27 \mathrm{kPa}$ dan $201.69 \mathrm{kPa}$.Adapun nilai Tensile Strength Retained (TSR) dari hasil uji tersebut adalah $65.43 \%$. 
Hasil pengujian kuat tekan bebas untuk varian kadar Foam Bitumen 2\% dengan variasi kadar air $80 \%, 90 \%, 100 \%$, dan $110 \%$ terhadap KAO adalah sebagai berikut :

Tabel 18. Hasil Uji UCS Kadar Foam Bitumen 2\% Variasi Kadar Air

\begin{tabular}{|c|c|c|c|c|c|c|c|c|c|c|c|c|c|c|c|}
\hline \multirow{3}{*}{ NAMA BENDA UJI } & \multirow{3}{*}{$\begin{array}{c}\text { No. } \\
\text { Benda } \\
\text { Uji }\end{array}$} & \multirow{3}{*}{$\begin{array}{c}\text { Tanggaal } \\
\text { Pembuatan }\end{array}$} & \multirow{3}{*}{\begin{tabular}{|l|} 
Tanggaal \\
Pengujian
\end{tabular}} & \multirow{2}{*}{ Umur } & \multirow{2}{*}{\begin{tabular}{|c|} 
Massa \\
Benda Uji \\
\end{tabular}} & \multirow{2}{*}{$\begin{array}{c}\text { Bobot } \\
\text { Isi }\end{array}$} & \multicolumn{3}{|c|}{ DIMENSI } & \multirow{2}{*}{\begin{tabular}{|l|} 
Luas \\
Bidang \\
\end{tabular}} & \multirow{2}{*}{$\begin{array}{l}\text { Gaya } \\
\text { Tekan }\end{array}$} & \multirow{2}{*}{$\begin{array}{c}\text { Kuat } \\
\text { Tekan } \\
\end{array}$} & \multirow{2}{*}{\begin{tabular}{|c|} 
Kuat Tekan \\
Rata-rata
\end{tabular}} & \multirow{2}{*}{$\begin{array}{c}\text { KOREKSI } \\
\text { T/D }\end{array}$} & \multirow{2}{*}{ KUAT TEKAN } \\
\hline & & & & & & & $\mathbf{P}$ & Latau D & $T$ & & & & & & \\
\hline & & & & (Hari) & (g) & $\left(\mathrm{g} / \mathrm{cm}^{3}\right)$ & $(\mathrm{cm})$ & $(\mathrm{cm})$ & $(\mathrm{cm})$ & $\left(\mathrm{cm}^{2}\right)$ & (kgf) & $\left(\mathrm{kgf} / \mathrm{cm}^{2}\right)$ & $\left(\mathrm{kgf} / \mathrm{cm}^{2}\right)$ & & (kPa) \\
\hline \multirow{2}{*}{ FB 2\% - 110\% KAO } & $\overline{11}$ & \begin{tabular}{|l|}
$11 / 1 / 2016$ \\
\end{tabular} & \begin{tabular}{|l|}
$11 / 8 / 2016$ \\
\end{tabular} & $\overline{77}$ & 3174 & & & 10 & 20 & $\begin{array}{l}78.54 \\
\end{array}$ & 370 & $4 \overline{4.71}$ & \multirow{2}{*}{4.77} & \multirow{2}{*}{0.96} & \multirow{2}{*}{452.18} \\
\hline & 2 & \begin{tabular}{l|}
$11 / 1 / 2016$ \\
\end{tabular} & \begin{tabular}{|l|}
$11 / 8 / 2016$ \\
\end{tabular} & 7 & 3173 & & & 10 & 20 & 78.54 & 380 & 4.84 & & & \\
\hline & & & & & & & & & & & & & & & \\
\hline \multirow{2}{*}{ FB $2 \%$ - $100 \%$ KAO } & 1 & $11 / 1 / 2016$ & \begin{tabular}{|l|}
$11 / 8 / 2016$ \\
\end{tabular} & 7 & 3174 & & & 10 & 20 & 78.54 & 590 & 7.51 & \multirow{2}{*}{7.64} & \multirow{2}{*}{0.96} & \multirow{2}{*}{723.49} \\
\hline & 2 & 11/1/2016 & \begin{tabular}{|l|}
$11 / 8 / 2016$ \\
\end{tabular} & 7 & 3189 & & & 10 & 20 & 78.54 & 610 & 7.77 & & & \\
\hline \multirow{3}{*}{ FB $2 \%$ - $90 \%$ KAO } & & & & & & & & & & & & & \multirow{3}{*}{7.07} & \multirow{3}{*}{0.96} & \\
\hline & 1 & $11 / 1 / 2016$ & $11 / 8 / 2016$ & 7 & 3172 & & & 10 & 20 & 78.54 & 570 & 7.26 & & & \multirow{2}{*}{669.22} \\
\hline & 2 & $11 / 1 / 2016$ & $11 / 8 / 2016$ & 7 & 3167 & & & 10 & 20 & 78.54 & 540 & 6.88 & & & \\
\hline \multirow{2}{*}{ FB 2\% - 80\% KAO } & 1 & $11 / 1 / 2016$ & $11 / 8 / 2016$ & 7 & 3169 & & & 10 & 20 & 78.54 & 560 & 7.13 & \multirow{2}{*}{6.94} & \multirow{2}{*}{0.96} & \multirow{2}{*}{657.17} \\
\hline & 2 & $11 / 1 / 2016$ & \begin{tabular}{|l|}
$11 / 8 / 2016$ \\
\end{tabular} & 7 & 3175 & & & 10 & 20 & 78.54 & 530 & 6.75 & & & \\
\hline & & & & & & & & & & & & & & & \\
\hline & & & & & & & & & & & & & & & \\
\hline \multirow[t]{2}{*}{ CATATAN LAIN : } & & & & & & & & & & & & & & & \\
\hline & \multicolumn{2}{|c|}{ Syarat Min $700 \mathrm{kPa}$} & & & & & & & & & & & & & \\
\hline
\end{tabular}

Nilai kuat tekan bebas untuk kadar foam bitumen $2 \%$ tertinggi dicapai pada kadar air $100 \%$ terhadap KAO sebesar $723,49 \mathrm{kPa}$. Sedangkan nilai terendah pada kadar air $110 \% \mathrm{KAO}$ sebesar 452,18 kPa.

\section{Analisis Indirect Tensile Strength}

a. Hubungan antara ITS dan kadar foam bitumen menunjukkan nilai optimum pada kadar foam $2 \%$ dan kadar air $80 \%$ terhadap Kadar Air Optimum dimana nilai ITS keringnya adalah $291,92 \mathrm{kPa}$ dan ITS rendamannya adalah 231,57 kPa. Sedangkan nilai ITS kering dan ITS rendaman rata-rata adalah $288,79 \mathrm{kPa}$ dan $217,79 \mathrm{kPa}$. Serta nilai TSRnya $75,41 \%$.

b. Hubungan antara ITS dan kadar foam bitumen menunjukkan nilai optimum pada kadar foam $2 \%$ dan kadar air 90\% terhadap Kadar Air Optimum dimana nilai ITS keringnya adalah $277,88 \mathrm{kPa}$ dan ITS rendamannya adalah $205,21 \mathrm{kPa}$. Sedangkan untuk nilai ITS kering dan rendaman rata-rata adalah $272,60 \mathrm{kPa}$ dan 200,43 kPa. Serta nilai TSR nya adalah $73,52 \%$.

c. Pada kondisi kadar foam bitumen $2 \%$ nilai optimumnya berada pada kadar air $100 \%$ terhadap Kadar Air Optimum dimana nilai ITS keringnya adalah $301,04 \mathrm{kPa}$ dan ITS rendamannya adalah $228,01 \mathrm{kPa}$. Sedangkan untuk nilai ITS kering dan rendaman rataratanya adalah $286,55 \mathrm{kPa}$ dan $218,80 \mathrm{kPa}$, serta nilai TSR nya adalah $76,36 \%$.

d. Pada kondisi kadar foam bitumen $2 \%$ nilai optimumnya berada pada kadar air $110 \%$ terhadap Kadar Air Optimum dimana nilai ITS keringnya adalah $322,54 \mathrm{kPa}$ dan ITS rendamannya adalah $211,61 \mathrm{kPa}$. Sedangkan untuk nilai ITS kering dan rendaman rataratanya adalah $308,27 \mathrm{kPa}$ dan $201,69 \mathrm{kPa}$, serta nilai TSR nya adalah $65,43 \%$.

Dari penelitian yang dilakukan diketahui bahwa pada kondisi kadar air $110 \%$ terhadap Kadar Air Optimum (KAO), kadar foam bitumen $2 \%$ mencapai nilai ITS kering tertinggi yaitu 322,54 $\mathrm{kPa}$, tetapi nilai TSR nya hanya mencapai $65,43 \%$ yang berada jauh dibawah nilai yang disyaratkan yaitu $80 \%$.

Sedangkan pada kondisi kadar air 90\% terhadap Kadar Air Optimum (KAO), kadar foam bitumen $2 \%$ mencapai nilai ITS kering terendah yaitu $277,80 \mathrm{kPa}$ dan ITS rendamannya adalah $205,21 \mathrm{kPa}$ dengan nilai TSR nya hanya mencapai $73,52 \%$ dibawah nilai yang disyaratkan yaitu $80 \%$.

\section{Analisis Unconfined Compressive Strength}

a. Hubungan antara UCS dan kadar foam bitumen menunjukkan nilai optimum pada kadar foam $2 \%$ dan kadar air 100\% terhadap Kadar Air Optimum dimana nilai UCS nya adalah $723,49 \mathrm{kPa}$. Nilai tersebut berada diatas nilai yang disyaratkan yaitu $700 \mathrm{kPa}$. 
b. Nilai UCS pada kadar air $80 \%$, $90 \%$ dan $100 \%$ terhadap Kadar Air Optimum pada berbagai kadar foam menunjukkan selisih nilai yang rapat meskipun pada kadar air $80 \%$ terhadap Kadar Air Optimum nilai UCS-nya sebesar 657,17 kPa yang berada dibawah nilai yang disyaratkan yaitu $700 \mathrm{kPa}$.

c. Nilai UCS pada kadar air $110 \%$ terhadap Kadar Air Optimum pada penentuan kadar foam $2 \%$ menunjukkan penurunan nilai yang sangat besar yaitu $452,18 \mathrm{kPa}$, nilai tersebut jauh dibawah nilai UCS yang disyaratkan yaitu $700 \mathrm{kPa}$.

\section{SIMPULAN}

Dari hasil analisis dan pembahasan yang telah diuraikan, maka dapat disimpulkan sebagai berikut :

a. Kadar air yang digunakan pada sampel kadar foam bitumen sangat berpengaruh terhadap kuat tarik tak langsung (Indirect Tensile Strength/ITS) dan kuat tekan bebas (Unconfined Compressive Strength/UCS) dari campuran dingin daur ulang dengan foam bitumen.

b. Nilai ITS, TSR dan UCS terbaik dicapai pada kadar foam yang ditentukan sebesar $2 \%$ dan kadar air optimum 100\% yaitu masing-masing dihasilkan nilai optimum sebagai berikut ITSkering $301,04 \mathrm{kPa}$, ITSrendam 218,80 kPa, TSR 76,36\%, dan UCS 723,49 $\mathrm{kPa}$.

c. Penambahan kadar air melebihi kadar air 100\% terhadap Kadar Air Optimum secara signifikan sangat berpengaruh terhadap nilai UCS, dimana pada uji penelitian ini menunjukkan penurunan yang drastis terhadap nilai UCS pada kadar air $110 \%$ terhadap Kadar Air Optimum. Nilai UCS yang dihasilkan dengan KAO 110\% sebesar 452,18 .

\section{SARAN}

Beberapa saran dapat disampaikan untuk lebih menyempurnakan hasil penelitian yang telah dilakukan, yaitu :

a. Perlu dilakukan penelitian lanjutan mengenai optimasi variasi penggunaan kadar foam bitumen dengan berbagai variasi penambahan kadar air optimum yang diteliti sehingga akan diketahui nilai ITS, TSR, dan UCS yang paling tepat.

b. Perlu dilakukan penelitian lanjutan mengenai pengaruh gradasi agregat terhadap nilai ITS, TSR, dan UCS dari campuran dingin dengan foam bitumen.

c. Kesiapan dan control alat pencampur CMRFB di lapangan harus intens karena sangat berpengaruh terhadap kualitas campuran.

d. Uji skala laboratorium pada penelitian yang telah dilakukan menunjukkan bahwa pelaksanaan CMRFB di lapangan, terutama sekali pada posisi on site pelaksanaannya, butuh ketelitian pada pelaksanaan dan pengawasan berkaitan dengan ketepatan penambahan air pada saat pencampuran foam dan agregat gabungan.

\section{DAFTAR PUSTAKA}

Anas Aly, M. 2007. Teknik Dasar dan Potensi Daur Ulang Konstruksi Jalan. Yayasan Pengembang Teknologi dan Manajemen, Jakarta

Badan Penelitian dan Pengembangan PU. 2007. Spesifikasi Khusus Campuran Beraspal Dingin Lapis Pondasi dengan Foam Bitumen. Departemen Pekerjaan Umum, Jakarta

Csanyi, L.H. 1957. Foam Asphalt in Bituminous Paving Mixes. Highway Research Board Bulletin Vol. 10 No.160

Djoko Widajat. 2008. Daur Ulang Campuran Dingin dengan Bahan Pengikat Foam Bitumen. Kolokium Puslitbang Jalan dan Jembatan TA.2008

Nyoman Suaryana. 2009. Kajian Pelaksanaan Teknologi Daur Ulang dengan Campuran Beraspal Panas di Ruas Jalan Cirebon - Losari. Pusat Penelitian dan Pengembangan Jalan dan Jembatan, Jakarta 
Ramanujam, J.M, Jones, J.D. 2000. Characterisation of Foam Bitumen Stabilization. Road System and Engineering Technology Forum, Queensland Australia

Romanoschi, S.A, M.Hossain, M.Heitzman, and A.J.Gisi. 2003. Foam Asphalt Stabilized Reclaimed Asphalt Pavement: A Promising Technology for Mid-Western Roads. Proceeding of 2003 MidContinent Transportation Research Symposium, Ames, lowa

Saleh, M.F. 2004. Characterisation of Foam Bitumen Quality and The Mechanical Properties of Foam Stabilised Mixes. TRB, National Research Council, Washington, D.C.

Sunarjono, S. 2007. Tensile Strength and Stiffness Modulus of Foam Asphalt Applied to A Grading Representative of Indonesian Road Recycled Pavement Materials. Jurnal Dinamika Teknik Sipil Vol. 7 No 1

Tjitjik Wasiah Suroso. 2009. Meningkatkan Mutu Aspal di Perkerasan Jalan yang Telah Lapuk dengan Cara Dingin. Jurnal Litbang Jalan, Vol.26 No.1 April 2009

Wirtgen, Gmbh. 2004. Cold Recycling Manual. Hohner Strasse 2.53578 Windhagen, Germany. 